Francoise Lunel Fabiani, Professor, Series Editor

\title{
Epidemiology of hepatitis C virus infection
}

\author{
Miriam J Alter
}

Miriam J Alter, Institute for Human Infections and Immunity, University of Texas Medical Branch, Galveston, Texas USA 77555 , United States

Correspondence to: Miriam J Alter, PhD, University of Texas Medical Branch, Mail Route 0435, 301 University Boulevard, Galveston, Texas 77555, United States.mjalter@utmb.edu

Telephone: +1-409-7470229 Fax: +1-409-7470220

Received: 2007-01-31 Accepted: 2007-02-13

\begin{abstract}
Globally, hepatitis C virus (HCV) has infected an estimated 130 million people, most of whom are chronically infected. HCV-infected people serve as a reservoir for transmission to others and are at risk for developing chronic liver disease, cirrhosis, and primary hepatocellular carcinoma (HCC). It has been estimated that HCV accounts for $27 \%$ of cirrhosis and $25 \%$ of HCC worldwide. HCV infection has likely been endemic in many populations for centuries. However, the wave of increased HCV-related morbidity and mortality that we are now facing is the result of an unprecedented increase in the spread of HCV during the $20^{\text {th }}$ century. Two $20^{\text {th }}$ century events appear to be responsible for this increase; the widespread availability of injectable therapies and the illicit use of injectable drugs.
\end{abstract}

(c) 2007 The WJG Press. All rights reserved.

Key words: Hepatitis C virus; Global epidemiology; Incidence; Prevalence; Transmission; Natural history

Alter MJ. Epidemiology of hepatitis C virus infection. World J Gastroenterol 2007; 13(17): 2436-2441

http://www.wjgnet.com/1007-9327/13/2436.asp

\section{PREVALENCE AND INCIDENCE}

The estimated global prevalence of $\mathrm{HCV}$ infection is $2.2 \%$, corresponding to about $130000000 \mathrm{HCV}$-positive persons worldwide (Figure 1) ${ }^{[1]}$. Because many countries lack data, this estimate is based on weighted averages for regions rather than individual countries. Region-specific estimates range from $<1.0 \%$ in Northern Europe to $>2.9 \%$ in Northern Africa. The lowest prevalence (0.01\%-0.1\%) has been reported from countries in the United Kingdom and Scandinavia; the highest prevalence $(15 \%-20 \%)$ has been reported from Egypt ${ }^{[2,3]}$. An estimated $27 \%$ of cirrhosis and $25 \%$ of HCC worldwide occur in HCV-infected people ${ }^{[4]}$.

There are both geographic and temporal differences in the patterns of HCV infection ${ }^{[5]}$. For example, vastly different countries, including the United States, Australia, Turkey, Spain, Italy, and Japan, belong to regions of the world with similar overall average prevalences of $\mathrm{HCV}$ infection $(1.0 \%-1.9 \%)$, but have different patterns of age-specific prevalence (Figure 2A). In the United States, prevalence is highest among persons 30-49 years old, who account for two-thirds of all infections, and lower than average among persons less than 20 and greater than 50 years old ${ }^{[6,7]}$. This pattern indicates that most $\mathrm{HCV}$ transmission occurred in the last 20-40 years, and primarily among young adults, a pattern similar to that observed in Australia ${ }^{[8]}$. In the United States ${ }^{[9,10]}$, Australia ${ }^{[11]}$, and countries in western and northern Europe with similar HCV epidemiology ${ }^{[12,13]}$, the greatest variations in prevalence occur among persons with different risk factors for infection.

In contrast, the age-specific prevalences of $\mathrm{HCV}$ infection increase steadily with age in Turkey, Spain, Italy, Japan, and China, (Figure 2A) ${ }^{[14-18]}$. In these countries, persons $>50$ years old account for most infections, which suggests a cohort effect in which the risk for HCV infection was higher in the distant past, i.e., 40-60 years previously. In many countries with this pattern, the greatest variations in HCV prevalence occur geographically. In Italy, Japan and China, for example, there are hyperendemic areas of the country in which older persons have an HCV prevalence 20 -fold greater than the average overall and 1.5-2-fold greater than the prevalence among older persons in other areas of the country ${ }^{[19-22]}$.

The highest HCV prevalence in the world occurs in Egypt, where the prevalence of infection increases steadily with age, and high rates of infection are observed among persons in all age groups (Figure $2 \mathrm{~B})^{[4,23]}$. This pattern indicates an increased risk in the distant past followed by an ongoing high risk for acquiring HCV infection, although there are regional differences in average overall prevalence ${ }^{[4,24]}$.

Determining the incidence of HCV infection (i.e., the rate of newly acquired infections) is difficult because most acute infections are asymptomatic, available assays do not distinguish acute from chronic or resolved infection, and most countries do not systematically collect data on cases of acute disease. Even in countries with well-established surveillance systems, acute disease reporting systems 


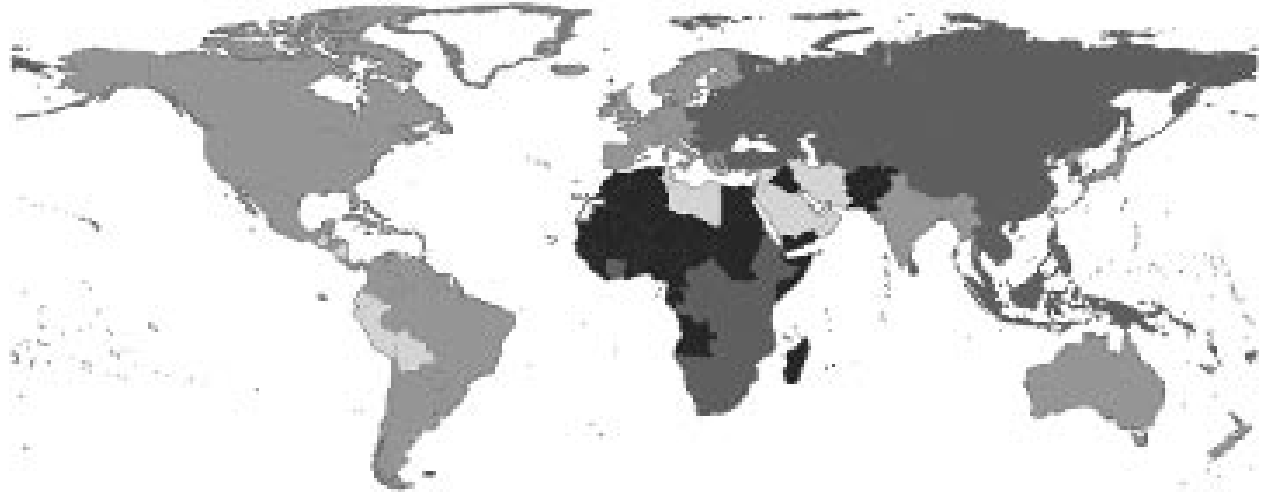

Figure 1 Estimated HCV prevalence by region ${ }^{[1]}$.

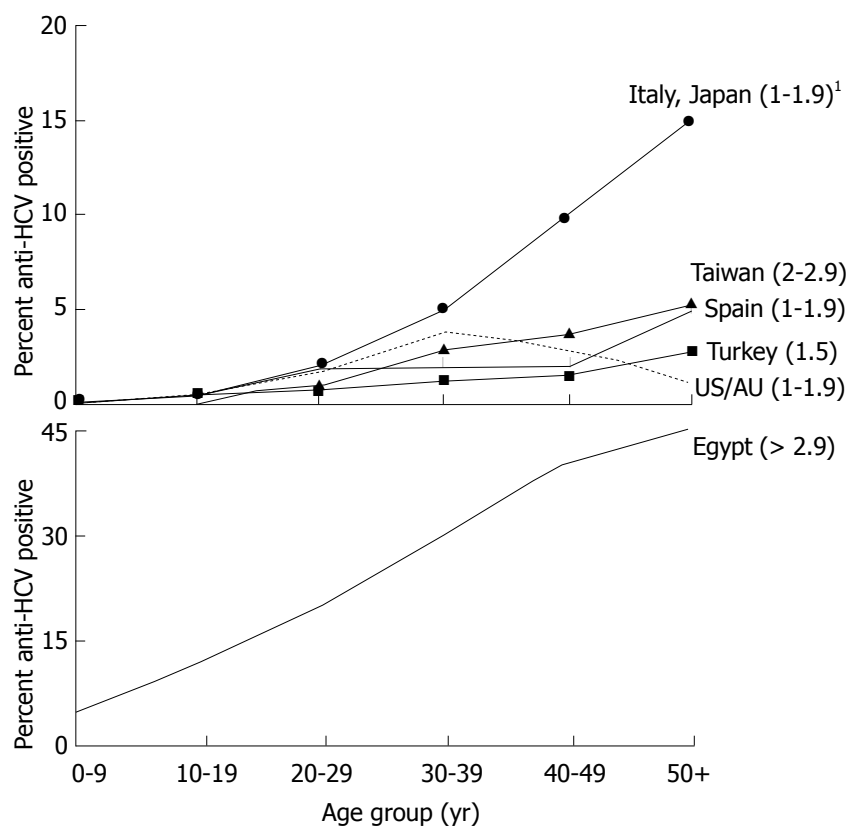

Figure 2 Age-Specific prevalence of antibody to hepatitis $C$ virus by selected countries. ${ }^{1}$ Numbers in parentheses indicate average regional prevalence in which country resides (see Figure 1).

underestimate the incidence of $\mathrm{HCV}$ infection ${ }^{[25-27]}$. For several countries, mathematical models have been used to infer trends in incidence, which rely on the assumption that current age-specific prevalence reflects the cumulative risk of acquiring infection.

In the United States, trends in HCV incidence were modeled using age-specific incidence from reported cases of acute disease $\mathrm{e}^{[28]}$ and age-specific prevalence from a cross-sectional national survey ${ }^{[6]}$. This model showed a large increase in the incidence of newly acquired HCV infections from the late 1960 s to the early $1980 \mathrm{~s}^{[29]}$. The estimated annual incidence was low (18 per 100000$)$ before 1965 , increased steadily through 1980 , and remained high (130 per 100000) through 1989, corresponding to an average of 240000 infections per year in the 1980 s. Since 1989, the incidence of reported cases of hepatitis $C$ has declined by more than $80 \%^{[30]}$, consistent with the finding that the national seroprevalence of infection remained unchanged between 1988 and $2002^{[7]}$. The rate of new HCV infections also declined in Italy in the 1990s according to reported cases of acute disease ${ }^{[27]}$. In both the United States and Italy, most newly acquired infections are in young adults $(30-35 \text { years old })^{[30,31]}$. A model of $\mathrm{HCV}$ burden in France, which employed death rates from hepatocellular carcinoma in addition to cross-sectional seroprevalence studies to estimate past incidence, showed a trend similar to that of the United States with increasing incidence through the $1980 \mathrm{~s}^{[32]}$, whereas an alternative approach to modeling disease burden in Australia showed a steady increase in new HCV infections in that country from 1961-2001 ${ }^{[8]}$.

Several other countries have measured HCV infection incidence by determining the rate of seroconversions in $\mathrm{HCV}$-negative cohorts followed over time. Cohort studies conducted in hyperendemic areas in Taiwan and Japan found incidence rates of HCV infection of 110/10000 and $28-36 / 10000$ persons, respectively ${ }^{[15,22,33]}$. The mean age of persons with newly acquired HCV infection was 50 years in the Taiwan cohort and 40 and 60 years, respectively, in the two Japan cohorts. Cohort studies in Egypt found incidence rates of $0.8 / 1000$ person-years in an area of Upper Egypt where the background prevalence was $9 \%$ and $6.8 / 1000$ in the Nile Delta where the background prevalence was $24 \%{ }^{[34]}$. Sixty-seven percent of the incident infections were in persons $<20$ years old.

Because chronic liver disease may develop many years after infection, the past incidence is a major determinant of the future burden of $\mathrm{HCV}$-associated complications ${ }^{[35]}$. In the United States and other countries where the emergence of HCV infection is a more recent event, the full magnitude of the burden of HCV-related chronic liver disease has yet to be realized as the duration of infection among most infected persons has not reached the point at which complications from chronic liver disease typically occur $^{[29,32]}$. In countries where the emergence of HCV infection occurred in the distant past (such as Japan and Italy), the burden of HCV-related chronic disease already might have reached its highest magnitude, but changes in disease transmission patterns that result in younger persons acquiring infection could result in future increases in chronic disease as this cohort ages ${ }^{[36]}$. In Egypt, where 
Table 1 Importance of different exposures to HCV transmission patterns in low, moderate and high prevalence areas worldwide

\begin{tabular}{llll}
\hline & \multicolumn{3}{l}{ The extent exposure contributes to } \\
& HCV transmission by level of HCV prevalence \\
\hline Exposure & Low & Moderate & High \\
Injecting drug use & ++++ & ++ & + \\
Transfusions (unscreened) & +++ & +++ & +++ \\
Unsafe therapeutic injections & + & +++ & ++++ \\
Occupational & + & + & + \\
Perinatal & + & + & + \\
High-risk sex & ++ & + & + - \\
\hline
\end{tabular}

there has been an ongoing high risk for decades, the high magnitude of the current burden of HCV-related chronic disease is predicted to continue into the future ${ }^{[37]}$.

\section{MODES OF TRANSMISSION}

The most efficient transmission of HCV is through large or repeated direct percutaneous exposures to blood (e.g., transfusion or transplantation from infectious donors, injecting drug use $)^{[10]}$. HCV is less efficiently transmitted by single small dose percutaneous exposures (e.g., accidental needlesticks) ${ }^{[10,38]}$ or by mucosal exposures to blood or serum-derived fluids (e.g., birth to an infected mother, sex with an infected partner $)^{[10,39,40]}$.

There is also evidence that the environment can serve as a reservoir for infectious virus. HCV transmission by inapparent percutaneous exposures has been caused by cross-contamination from reused needles and syringes, multiple-use medication vials, infusion bags, and injectingdrug use paraphernalia ${ }^{[41,42]}$. These epidemiologic data implicating transmission from environmental sources of $\mathrm{HCV}$ are supported by an experimental study that demonstrated the infectivity of $\mathrm{HCV}$ in blood after exposure to drying and storage at room temperature ${ }^{[43]}$. Similar results have been reported for hepatitis B virus $(\mathrm{HBV})^{[44]}$. However, the risk for transmission of $\mathrm{HBV}$ from such inapparent exposures appears to be greater, probably because of differences in characteristics between the two viruses, including the longer environmental survival of $\mathrm{HBV}^{[44]}$ and concentrations in the blood of infected persons two- to four-logs higher ${ }^{[45]}$.

However, in the recent cohort study in Egypt, the strongest predictor of incident HCV infection was having an anti-HCV-positive family member ${ }^{[34]}$. Among those that did, incidence was 5.8/1000 PY compared with 1.0/1000 PY $(P<0.01)$ among those with no positive family members. The highest incidence rate (14.1/1000 PY) was in children younger than 10 who were living in households with an anti-HCV-positive parent. The study did not determine the factors responsible for this association.

\section{RISK FACTORS}

Risk factors associated with acquiring infection as determined from cohort (prospective) and case control (retrospective) studies of persons with acute disease (or infection) have included transfusion of blood and blood products and transplantation of solid organs from infected donors, injecting drug use, unsafe therapeutic injections, occupational exposure to blood (primarily contaminated needle sticks), birth to an infected mother, sex with an infected partner, and sex with multiple partners ${ }^{[9,10]}$. Among these, transfusion from unscreened donors, injecting drug use, and unsafe therapeutic injections have been the most important, however, there are temporal and geographical differences in the extent to which these risk factors have contributed to HCV transmission (Table 1).

\section{BLOOD TRANSFUSION AND IATROGENIC EXPOSURES}

Transfusion-associated HCV infection was a worldwide risk before $\mathrm{HCV}$ testing became available. It has been virtually eliminated in those countries that implemented routine $\mathrm{HCV}$ testing of donors ${ }^{[46]}$, but in others, receipt of blood transfusions remains an important source for infection. Some countries continue to use commercial donors to supplement their blood supplies, have not considered blood safety a priority, and lack the resources to implement donor screening ${ }^{[47]}$.

Of even greater importance in the spread of $\mathrm{HCV}$, are unsafe therapeutic injections performed by both professionals and non-professionals. It has been estimated that approximately 2 million HCV infections are acquired annually from contaminated health care injections, and may account for up to $40 \%$ of all HCV infections worldwide ${ }^{[48]}$. In many developing countries, supplies of sterile syringes may be inadequate or nonexistent, non-professionals often administer injections outside the medical setting, and injections are often given to deliver medications that could otherwise be delivered by the oral route. Reuse of glass syringes during the early campaign to treat schistosomiasis in Egypt appeared to be responsible for the largest outbreak of iatrogenic transmission of a bloodborne pathogen ever recorded ${ }^{[3]}$. In addition to unsafe injection practices, lack of attention to appropriate cleaning and disinfection of equipment used in hospital and dental settings also may be a source for HCV transmission.

\section{ILLEGAL INJECTING DRUG USE}

Injecting drug use has been the predominant mode of transmission during the past 40 years in the United States and Australia, and now accounts for most newly acquired infections in many other countries, including those in Western, Northern, and Southern Europe. Although cumulative infection rates among young injection drug users during the first 2-3 years of injecting have slowed in recent years, declining from $80 \%$ during the late 1980 s to $30 \%$ during the late 1990 s, incidence among new injectors remains high, ranging from $15 \%$ to $>$ $30 \%$ annually ${ }^{[49]}$. Fewer sharing partners are necessary to sustain HCV transmission than are necessary for other bloodborne viruses ${ }^{[50]}$, and indirect drug sharing and preparation practices, such as backloading and sharing cotton, cooker, and rinse water, have been associated with $\mathrm{HCV}$ transmission ${ }^{[51]}$. These results indicate that harm 
reduction messages and access to drug treatment need to be expanded to prevent new HCV infections, particularly among young injectors.

\section{OTHER EXPOSURES}

In contrast, the contributions of occupational, perinatal, and high-risk sexual exposures have been relatively constant over time and with substantially less geographic variation (Table 1$)^{[52]}$. The relatively low efficiency of these routes for transmission compared to those involving large or repeated percutaneous exposures may explain these differences.

Occupational transmission of HCV infection is largely confined to health care workers who have sustained contaminated needlestick injuries; average incidence of anti-HCV seroconversion from an HCV-positive source is $1.8 \%$; transmission has been associated with hollow-bore needles and deep injuries ${ }^{[53]}$. Transmission rarely occurs from mucous membrane or non-intact skin exposures to blood $^{[54]}$, and no transmission to health care workers has been documented from intact skin exposures to blood. Furthermore, the prevalence of HCV infection among health care workers, including orthopedic, general, and oral surgeons, is no greater than the general population, averaging $1 \%-2 \%$, and is 10 times lower than that for $\mathrm{HBV}$ infection. Even more rarely, HCV-infected healthcare workers have transmitted to patients, and the risk was extremely low-averaging about $0.5 \%$, even for those episodes involving surgeons.

The rate of perinatal transmission of $\mathrm{HCV}$ is $4 \%$ to $7 \%$ per pregnancy and occurs only when HCV RNA is detectable in maternal serum at delivery. Transmission may be related to higher levels (above $10^{6}$ copies per $\mathrm{mL}$ ), although data on the effect of virus concentration have been inconsistent ${ }^{[39]}$. Prolonged labor after membrane rupture and internal fetal monitoring have been associated with perinatal infection ${ }^{[39,55]}$. There has been no association with vaginal delivery, caesarian section or breastfeeding. Co-infection with human immunodeficiency virus (HIV) increases the rate of transmission 4- to 5-fold.

The extent to which HCV is transmitted by sexual activity and under what circumstances is one of the most controversial aspects of the epidemiology of hepatitis C. The results of different types of studies have been inconsistent. The strongest evidence for heterosexual activity as a risk factor for $\mathrm{HCV}$ infection came from case-control studies of persons with acute non-A, non-B hepatitis (now known as hepatitis C) in the United States during the 1970s and 1980s, which identified sex with an infected partner or with multiple partners as independently associated with acquiring disease ${ }^{[56,57]}$. Since then, 15\%-20\% of cases of acute hepatitis $\mathrm{C}$ have reported no other risk factor except one of these sexual exposures. In contrast, no association was found with male homosexual activity, and cross-sectional studies conducted since 1990 of men who have sex with men (MSM) and heterosexual persons in long term monogamous relationships with a partner with chronic HCV have found little evidence for sexual transmission of $\mathrm{HCV}^{[10,40]}$. One possible explanation for these apparent inconsistencies is that HCV is more likely to be transmitted by sexual intercourse when the infected partner is in the early phase of acute infection; virus concentration is high and there is no antibody to complex with antigen. The early case-control studies of acute disease were performed when the incidence of $\mathrm{HCV}$ infection was at its peak. During that time a high proportion of the general adult population had a history of multiple sex partners ${ }^{[6]}$, which may have increased their probability of having sex with an infectious partner. A higher rate of sexual transmission of $\mathrm{HCV}$ during the acute phase of infection in combination with a high proportion of persons having unsafe sex with multiple partners could explain the disproportionate amount of the HCV-related disease burden accounted for by sexual activity relative to the low efficiency by which the virus is transmitted by this mode, as well as the rare episodes of infection among partners of persons with chronic HCV. A similar association with acute hepatitis $C$ and multiple sex partners has been reported from Italy ${ }^{[58]}$, and since 2000, there have been reports from several European countries of episodes of acute hepatitis C among HIV-infected MSM $^{[59-62]}$.

Because of the wide variety of human activities that involve the potential for percutaneous exposure to blood or blood-derived body fluids, there are numerous other biologically-plausible modes of transmission besides those with clearly-demonstrated epidemiologic associations with infection. These include cosmetic procedures (tattooing, body-piercing), intranasal drug use, and religious or cultural practices such as ritual scarification, circumcision, acupuncture, and cupping. In most regions of the world, there are insufficient data to determine whether these risk factors make any measurable contribution to overall $\mathrm{HCV}$ transmission. In those countries where adequate studies have been done, none of these activities have been consistently associated with HCV transmission ${ }^{[9,63]}$.

\section{SUMMARY}

Thus, most of the HCV-related disease burden in developed countries has resulted from injection drug use, receipt of transfusions before donor screening, and high-risk sexual activity. In contrast, most of the disease burden in developing countries is related to receipt of unsafe therapeutic injections and contaminated blood. Characterizing the epidemiology of $\mathrm{HCV}$ infection in individual countries is crucial to developing and implementing effective preventive measures. In some, ensuring safe blood supplies and health-care related procedures are the highest priorities. In others, priorities need to focus on preventing injecting drug use, improving access to drug treatment, harm reduction counseling, and testing to identify $\mathrm{HCV}$-infected persons for medical evaluation and management.

\section{REFERENCES}

1 Global burden of disease (GBD) for hepatitis C. J Clin Pharmacol 2004; 44: 20-29

2 Shepard CW, Finelli L, Fiore AE, Bell BP. Epidemiology of hepatitis B and hepatitis B virus infection in United States children. Pediatr Infect Dis J 2005; 24: 755-760 
3 Frank C, Mohamed MK, Strickland GT, Lavanchy D, Arthur RR, Magder LS, El Khoby T, Abdel-Wahab Y, Aly Ohn ES, Anwar W, Sallam I. The role of parenteral antischistosomal therapy in the spread of hepatitis C virus in Egypt. Lancet 2000; 355: 887-891

4 Perz JF, Armstrong GL, Farrington LA, Hutin YJ, Bell BP. The contributions of hepatitis $B$ virus and hepatitis $C$ virus infections to cirrhosis and primary liver cancer worldwide. $J$ Hepatol 2006; 45: 529-538

5 Alter MJ, Hutin YJ, Armstrong GL. Epidemiology of hepatitis C. In: Liang TJ, Hoofnagle JH, editors. Hepatitis C. San Diego: Academic Press, 2000: 169-183

6 Alter MJ, Kruszon-Moran D, Nainan OV, McQuillan GM, Gao F, Moyer LA, Kaslow RA, Margolis HS. The prevalence of hepatitis $C$ virus infection in the United States, 1988 through 1994. N Engl J Med 1999; 341: 556-562

7 Armstrong GL, Wasley A, Simard EP, McQuillan GM, Kuhnert WL, Alter MJ. The prevalence of hepatitis $C$ virus infection in the United States, 1999 through 2002. Ann Intern Med 2006; 144: 705-714

8 Law MG, Dore GJ, Bath N, Thompson S, Crofts N, Dolan K, Giles W, Gow P, Kaldor J, Loveday S, Powell E, Spencer J, Wodak A. Modelling hepatitis $C$ virus incidence, prevalence and long-term sequelae in Australia, 2001. Int J Epidemiol 2003; 32: 717-724

9 Alter MJ. Prevention of spread of hepatitis C. Hepatology 2002; 36: $\mathrm{S} 93-\mathrm{S} 98$

10 Recommendations for prevention and control of hepatitis $\mathrm{C}$ virus (HCV) infection and $\mathrm{HCV}$-related chronic disease. Centers for Disease Control and Prevention. MMWR Recomm Rep 1998; 47: 1-39

11 Dore GJ, MacDonald M, Law MG, Kaldor JM. Epidemiology of hepatitis C virus infection in Australia. Aust Fam Physician 2003; 32: 796-798

12 Gérard C, Delwaide J, Vaira D, Bastens B, Servais B, Wain E, Bataille C, Daenen G, Belaïche J. Evolution over a 10 year period of the epidemiological profile of 1,726 newly diagnosed HCV patients in Belgium. J Med Virol 2005; 76: 503-510

13 Payan C, Roudot-Thoraval F, Marcellin P, Bled N, Duverlie G, Fouchard-Hubert I, Trimoulet P, Couzigou P, Cointe D, Chaput C, Henquell C, Abergel A, Pawlotsky JM, Hezode C, Coudé M, Blanchi A, Alain S, Loustaud-Ratti V, Chevallier P, Trepo C, Gerolami V, Portal I, Halfon P, Bourlière M, Bogard M, Plouvier E, Laffont C, Agius G, Silvain C, Brodard V, Thiefin G, Buffet-Janvresse C, Riachi G, Grattard F, Bourlet T, Stoll-Keller F, Doffoel M, Izopet J, Barange K, MartinotPeignoux M, Branger M, Rosenberg A, Sogni P, Chaix ML, Pol S, Thibault V, Opolon P, Charrois A, Serfaty L, Fouqueray B, Grange JD, Lefrère JJ, Lunel-Fabiani F. Changing of hepatitis $\mathrm{C}$ virus genotype patterns in France at the beginning of the third millenium: The GEMHEP GenoCII Study. J Viral Hepat 2005;12:405-413

14 Domínguez A, Bruguera M, Vidal J, Plans P, Salleras L. Community-based seroepidemiological survey of $\mathrm{HCV}$ infection in Catalonia, Spain. J Med Virol 2001; 65: 688-693

15 Sun CA, Chen HC, Lu SN, Chen CJ, Lu CF, You SL, Lin SH. Persistent hyperendemicity of hepatitis $C$ virus infection in Taiwan: the important role of iatrogenic risk factors. J Med Virol 2001; 65: 30-34

16 Sun CA, Chen HC, Lu CF, You SL, Mau YC, Ho MS, Lin $\mathrm{SH}$, Chen CJ. Transmission of hepatitis C virus in Taiwan: prevalence and risk factors based on a nationwide survey. $J$ Med Virol 1999; 59: 290-296

17 Campello C, Poli A, Dal MG, Besozzi-Valentini F. Seroprevalence, viremia and genotype distribution of hepatitis $C$ virus: a community-based population study in northern Italy. Infection 2002; 30: 7-12

18 Sagnelli E, Stroffolini T, Mele A, Almasio P, Coppola N, Ferrigno L, Scolastico C, Onofrio M, Imparato M, Filippini P. The importance of $\mathrm{HCV}$ on the burden of chronic liver disease in Italy: a multicenter prevalence study of 9,997 cases. J Med Virol 2005; 75: 522-527

19 Zhang M, Sun XD, Mark SD, Chen W, Wong L, Dawsey SM,
Qiao YL, Fraumeni JF, Taylor PR, O'Brien TR. Hepatitis C virus infection, Linxian, China. Emerg Infect Dis 2005; 11: 17-21

20 Di Stefano R, Stroffolini T, Ferraro D, Usticano A, Valenza LM, Montalbano L, Pomara G, Craxì A. Endemic hepatitis $C$ virus infection in a Sicilian town: further evidence for iatrogenic transmission. J Med Virol 2002; 67: 339-344

21 Maio G, d'Argenio P, Stroffolini T, Bozza A, Sacco L, Tosti ME, Intorcia M, Fossi E, d'Alessio G, Kondili LA, Rapicetta M, Mele A. Hepatitis $C$ virus infection and alanine transaminase levels in the general population: a survey in a southern Italian town. J Hepatol 2000; 33: 116-120

22 Okayama A, Stuver SO, Tabor E, Tachibana N, Kohara M, Mueller NE, Tsubouchi $\mathrm{H}$. Incident hepatitis $\mathrm{C}$ virus infection in a community-based population in Japan. J Viral Hepat 2002; 9: 43-51

23 Abdel-Aziz F, Habib M, Mohamed MK, Abdel-Hamid M, Gamil F, Madkour S, Mikhail NN, Thomas D, Fix AD, Strickland GT, Anwar W, Sallam I. Hepatitis C virus (HCV) infection in a community in the Nile Delta: population description and HCV prevalence. Hepatology 2000; 32: 111-115

24 Medhat A, Shehata M, Magder LS, Mikhail N, Abdel-Baki L, Nafeh M, Abdel-Hamid M, Strickland GT, Fix AD. Hepatitis c in a community in Upper Egypt: risk factors for infection. $\mathrm{Am}$ J Trop Med Hyg 2002; 66: 633-638

25 Hagan H, Snyder N, Hough E, Yu T, McKeirnan S, Boase J, Duchin J. Case-reporting of acute hepatitis B and C among injection drug users. J Urban Health 2002; 79: 579-585

26 Robotin MC, Copland J, Tallis G, Coleman D, Giele C, Carter L, Spencer J, Kaldor JM, Dore GJ. Surveillance for newly acquired hepatitis C in Australia. J Gastroenterol Hepatol 2004; 19: $283-288$

27 Spada E, Mele A, Ciccozzi M, Tosti ME, Bianco E, Szklo A, Ragni P, Gallo G, Balocchini E, Sangalli M, Lopalco PL, Moiraghi A, Stroffolini T. Changing epidemiology of parenterally transmitted viral hepatitis: results from the hepatitis surveillance system in Italy. Dig Liver Dis 2001; 33 778-784

28 Alter MJ, Hadler SC, Judson FN, Mares A, Alexander WJ, Hu PY, Miller JK, Moyer LA, Fields HA, Bradley DW. Risk factors for acute non-A, non-B hepatitis in the United States and association with hepatitis C virus infection. JAMA 1990; 264: 2231-2235

29 Armstrong GL, Alter MJ, McQuillan GM, Margolis HS. The past incidence of hepatitis $C$ virus infection: implications for the future burden of chronic liver disease in the United States. Hepatology 2000; 31: 777-782

30 Alter MJ. Epidemiology of hepatitis C. Hepatology 1997; 26: 62S-65S

31 Prati D, Capelli C, Silvani C, De Mattei C, Bosoni P, Pappalettera M, Mozzi F, Colombo M, Zanella A, Sirchia $\mathrm{G}$. The incidence and risk factors of community-acquired hepatitis C in a cohort of Italian blood donors. Hepatology 1997; 25: 702-704

32 Deuffic S, Buffat L, Poynard T, Valleron AJ. Modeling the hepatitis C virus epidemic in France. Hepatology 1999; 29 1596-1601

33 Fukuizumi K, Sata M, Suzuki H, Nakano H, Tanikawa K. Hepatitis $\mathrm{C}$ virus seroconversion rate in a hyperendemic area of HCV in Japan: a prospective study. Scand J Infect Dis 1997; 29: 345-347

34 Mohamed MK, Abdel-Hamid M, Mikhail NN, Abdel-Aziz F, Medhat A, Magder LS, Fix AD, Strickland GT. Intrafamilial transmission of hepatitis C in Egypt. Hepatology 2005; 42: 683-687

35 Perz JF, Alter MJ. The coming wave of HCV-related liver disease: dilemmas and challenges. J Hepatol 2006; 44: 441-443

36 Deuffic S, Poynard T, Valleron AJ. Correlation between hepatitis $C$ virus prevalence and hepatocellular carcinoma mortality in Europe. J Viral Hepat 1999; 6: 411-443

37 Deuffic-Burban S, Mohamed MK, Larouze B, Carrat F, Valleron AJ. Expected increase in hepatitis C-related mortality in Egypt due to pre-2000 infections. J Hepatol 2006; 44: 455-461

38 Puro V, Petrosillo N, Ippolito G. Risk of hepatitis C 
seroconversion after occupational exposures in health care workers. Italian Study Group on Occupational Risk of HIV and Other Bloodborne Infections. Am J Infect Control 1995; 23: 273-277

39 Roberts EA, Yeung L. Maternal-infant transmission of hepatitis C virus infection. Hepatology 2002; 36: S106-S113

40 Terrault NA. Sexual activity as a risk factor for hepatitis C. Hepatology 2002; 36: S99-105

41 Williams IT, Perz JF, Bell BP. Viral hepatitis transmission in ambulatory health care settings. Clin Infect Dis 2004; 38: 1592-1598

42 Hagan H, Thiede H, Weiss NS, Hopkins SG, Duchin JS, Alexander ER. Sharing of drug preparation equipment as a risk factor for hepatitis C. Am J Public Health 2001; 91: 42-46

43 Kamili S, Krawczynski K, McCaustland K, Li X, Alter MJ. Infectivity of hepatitis $C$ virus in plasma after drying and storing at room temperature. Infect Control Hosp Epidemiol 2007;28:519-524

44 Bond WW, Favero MS, Petersen NJ, Gravelle CR, Ebert JW, Maynard JE. Survival of hepatitis B virus after drying and storage for one week. Lancet 1981; 1: 550-551

45 Gilbert N, Corden S, Ijaz S, Grant PR, Tedder RS, Boxall EH. Comparison of commercial assays for the quantification of HBV DNA load in health care workers: calibration differences. J Virol Methods 2002; 100: 37-47

46 Busch MP, Glynn SA, Stramer SL, Strong DM, Caglioti S, Wright DJ, Pappalardo B, Kleinman SH. A new strategy for estimating risks of transfusion-transmitted viral infections based on rates of detection of recently infected donors. Transfusion 2005; 45: 254-264

47 Hladik W, Kataaha P, Mermin J, Purdy M, Otekat G, Lackritz E, Alter MJ, Downing R. Prevalence and screening costs of hepatitis $\mathrm{C}$ virus among Ugandan blood donors. Trop Med Int Health 2006; 11: 951-954

48 Hauri AM, Armstrong GL, Hutin YJ. The global burden of disease attributable to contaminated injections given in health care settings. Int J STD AIDS 2004; 15: 7-16

49 Des Jarlais DC, Diaz T, Perlis T, Vlahov D, Maslow C, Latka M, Rockwell R, Edwards V, Friedman SR, Monterroso E, Williams I, Garfein RS. Variability in the incidence of human immunodeficiency virus, hepatitis B virus, and hepatitis C virus infection among young injecting drug users in New York City. Am J Epidemiol 2003; 157: 467-471

50 Murray JM, Law MG, Gao Z, Kaldor JM. The impact of behavioural changes on the prevalence of human immunodeficiency virus and hepatitis $\mathrm{C}$ among injecting drug users. Int J Epidemiol 2003; 32: 708-714

51 Thorpe LE, Ouellet LJ, Hershow R, Bailey SL, Williams IT, Williamson J, Monterroso ER, Garfein RS. Risk of hepatitis C virus infection among young adult injection drug users who share injection equipment. Am J Epidemiol 2002; 155: 645-653

52 Alter MJ. Hepatitis C: fact versus fiction. In: Margolis HS, Alter MJ, Liang J, Dienstag J, editors. Viral Hepatitis and Liver Disease. Atlanta: International Medical Press, 2002: 310-315
53 Yazdanpanah Y, De Carli G, Migueres B, Lot F, Campins M, Colombo C, Thomas T, Deuffic-Burban S, Prevot $\mathrm{MH}$, Domart M, Tarantola A, Abiteboul D, Deny P, Pol S, Desenclos JC, Puro V, Bouvet E. Risk factors for hepatitis C virus transmission to health care workers after occupational exposure: a European case-control study. Clin Infect Dis 2005; 41: $1423-1430$

54 Beltrami EM, Kozak A, Williams IT, Saekhou AM, Kalish ML Nainan OV, Stramer SL, Fucci MC, Frederickson D, Cardo DM. Transmission of HIV and hepatitis $C$ virus from a nursing home patient to a health care worker. Am J Infect Control 2003, 31: 168-175

55 Mast EE, Hwang LY, Seto DS, Nolte FS, Nainan OV, Wurtzel H Alter MJ. Risk factors for perinatal transmission of hepatitis $\mathrm{C}$ virus $(\mathrm{HCV})$ and the natural history of $\mathrm{HCV}$ infection acquired in infancy. J Infect Dis 2005; 192: 1880-1889

56 Alter MJ, Gerety RJ, Smallwood LA, Sampliner RE, Tabor E, Deinhardt F, Frösner G, Matanoski GM. Sporadic non-A, non-B hepatitis: frequency and epidemiology in an urban U.S. population. J Infect Dis 1982; 145: 886-893

57 Alter MJ, Coleman PJ, Alexander WJ, Kramer E, Miller JK, Mandel E, Hadler SC, Margolis HS. Importance of heterosexual activity in the transmission of hepatitis $\mathrm{B}$ and non-A, non-B hepatitis. JAMA 1989; 262: 1201-1205

58 Mele A, Stroffolini T, Tosti ME, Corona R, Santonastasi F, Gallo G, Ragni P, Balocchini E, Bernacchia R, Moiraghi A. Heterosexual transmission of hepatitis $\mathrm{C}$ in Italy. J Med Virol 1999; 57: 111-113

59 Browne R, Asboe D, Gilleece Y, Atkins M, Mandalia S Gazzard B, Nelson M. Increased numbers of acute hepatitis $C$ infections in HIV positive homosexual men; is sexual transmission feeding the increase? Sex Transm Infect 2004; 80 326-327

60 Gambotti L, Batisse D, Colin-de-Verdiere N, DelaroqueAstagneau E, Desenclos JC, Dominguez S, Dupont C, Duval X, Gervais A, Ghosn J, Larsen C, Pol S, Serpaggi J, Simon A, Valantin MA, Velter A. Acute hepatitis C infection in HIV positive men who have sex with men in Paris, France, 2001-2004. Euro Surveill 2005; 10: 115-117

61 Götz HM, van Doornum G, Niesters HG, den Hollander JG, Thio HB, de Zwart O. A cluster of acute hepatitis $C$ virus infection among men who have sex with men--results from contact tracing and public health implications. AIDS 2005; 19 969-974

62 Rauch A, Rickenbach M, Weber R, Hirschel B, Tarr PE, Bucher HC, Vernazza P, Bernasconi E, Zinkernagel AS, Evison J, Furrer H. Unsafe sex and increased incidence of hepatitis C virus infection among HIV-infected men who have sex with men: the Swiss HIV Cohort Study. Clin Infect Dis 2005; 41: 395-402

63 Hwang LY, Kramer JR, Troisi C, Bull L, Grimes CZ, Lyerla R, Alter MJ. Relationship of cosmetic procedures and drug use to hepatitis $C$ and hepatitis B virus infections in a low-risk population. Hepatology 2006; 44: 341-351

S- Editor Liu $Y$ E- Editor Liu $Y$ 